\title{
PENGARUH PENATALAKSANAAN IMD TERHADAP KEBERHASILAN PEMBERIAN ASI EKSKLUSIF DI WILAYAH KERJA PUSKESMAS ONAN HASANG
}

\author{
Riance Mardiana Ujung ${ }^{1}$, Dimpu Rismawaty Nainggolan ${ }^{2}$ \\ 1, 2, Program Studi D3 Kebidanan Tarutung \\ *Email : ryanceujung@gmail.com
}

\begin{abstract}
Abstrak
Kebijakan inisiasi menyusu dini disosialisasikan Indonesia sejak Agustus 2007. WHO merekomendasikan semua bayi mendapatkan kolostrum yaitu ASI pada hari pertama dan kedua untuk melawan berbagai infeksi dan mendapatkan ASI sejak lahir selama 6 bulan. Tujuan penelitian mengetahui penatalaksanaan IMD terhadap keberhasilan pemberian ASI Eksklusif di wilayah kerja Puskesmas Onan Hasang. Penelitian ini merupakan penelitian kuantitatif dengan metode analitik dengan desain studi cross sectional untuk melihat pengaruh inisisasi menyusu dini terhadap pemberian Asi Eksklusif dengan Kriteria inklusi penelitian adalah ibu yang melahirkan normal. Teknik pengambilan sampel menggunakan accidental sampling sebanyak 42 responden. Hasil penelian diperoleh Mayoritas responden berdasarkan umur $20-35$ tahun sebanyak 32 responden $(76.2 \%)$ dengan hasil $\mathrm{p}=$ 1.00 , Mayoritas responden berdasarkan pendidikan adalah berpendidikan rendah $29(69 \%)$ dengan hasil $\mathrm{p}=0.678$, Karakteristik berdasarkan jumlah anak dengan hasil $\mathrm{p}=0.063$, Mayoritas responden berdasarkan karakteristik pendapatan adalah $>2$ jt sebanyak 31 responden $(73.8 \%)$ dengan hasil $p=1.000$, Mayoritas responden berdasarkan pekerjaan adalah bekerja sebanyak 23 responden $(54.8 \%$ ) dengan hasil $\mathrm{p}=0.000$, Mayoritas responden berdasarkan pelaksanaan IMD adalah tidak dilakukan sebanyak 25 responden (59.5\%) dengan hasil $\mathrm{p}=0.000$. Hasil uji multivariate menunjukkan bahwa jumlah anak (paritas) $p=0.112 \operatorname{Exp}(\mathrm{B}) 4.808$ yang artinya tidak ada pengaruh antara jumlah anak dengan pemberian ASI Eksklusif, sedangkan hasil multivariate dari pekerjaan $p=0.020 \operatorname{Exp}(B)$ 8.601 dan penatalaksaan IMD sebesar $\mathrm{p}=0.011 \operatorname{Exp}(\mathrm{B}) 11.792$ yang artinya ada pengaruh antara pekerjaan dan penatalaksanaan IMD dengan Pemberian ASI Eksklusif. Saran kepada ibu agar memberikan ASI Eksklusif kepada bayinya karena ASI Eksklusif lebih baik dari pada susu kaleng. ASI Ekslusif lebih baik dari pada susu kaleng.
\end{abstract}

Kata Kunci : Penatalaksanaan, IMD, Pemberian, ASI Eksklusif

\begin{abstract}
The effect of management of IMD to support exclusive breastfeeding on the success at Onan Hasang Public Health Center. The policy of early breastfeeding initiation has been socialized by Indonesia since August 2007. WHO asks all babies to get colostrum, namely breast milk on the first and second days to fight various infections and get breast milk from birth for 6 months. The purpose of the study was to find out the management of IMD to support exclusive breastfeeding in the work area of the Onan Hasang Public Health Center. This research is quantitative research with analytic method with cross-sectional study design to see the effect of early breastfeeding initiation on the provision of Asi ekslusive with the inclusion criteria of the study is that the mother produces normally. The sampling technique used an accidental sampling of 42 respondents. The results obtained by the majority of respondents based on age 20-35 years were 32 respondents (76.2\%) with the results of $p=$ 1.00 , the majority of respondents based on education with low education $29(69 \%)$ with the results of $p=0.678$, Characteristics based on the number of children with results $p=0.063$, the majority of respondents based on income characteristics are $>2$ million as many as 31 respondents (73.8\%) with the results of $p=1,000$, the majority of respondents based on works are 23 respondents (54.8\%) with results $p=0,000$, the majority respondents based on IMD tracking were not conducted as many as 25 respondents $(59.5 \%)$ with a result of $p=$ 0,000. Multivariate test results show the number of children (parity) $p=0,112 \operatorname{Exp}(B) 4,808$ which means there is no number of children with exclusive breastfeeding, while the multivariate results from work $p=0.020 \operatorname{Exp}(B)$ 8.601 and IMD management of $p=0.011$ Exp (B) 11,792 which means that there is a difference between work and management of IMD with Exclusive Breastfeeding. Suggestions for mothers to give exclusive breastfeeding to their babies because Exclusive breastfeeding is better than canned milk. Exclusive breast milk is better than canned milk.
\end{abstract}

Keywords: Management, breastfeeding, initiation, Giving, Exclusive 
Ujung, Riance Mardiana, \& Nainggolan Dimpu Rismawaty. Pengaruh Penatalaksanaan IMD

Terhadap Keberhasilan Pemberian Asi Eksklusif Di Wilayah Kerja Puskesmas Onan Hasang. Journal of Borneo Holistic Health, Vol.3, No. 1 Juni 2020 hal 26-33

\section{Pendahuluan}

ASI merupakan sumber gizi yang sangat ideal untuk bayi. ASI memiliki keunggulan dan keistimewaan sebagai nutrisi dibandingkan sumber nutrisi lainnya. Komponen makro dan mikro yang terkandung di dalam ASI sangat penting dibutuhkan pada tiap tahapan pertumbuhan bayi. Komponen makro terdiri dari karbohidrat, protein dan lemak sedangkan komponen mikro adalah vitamin dan mineral, (Wiji, 2013).

Kebijakan inisiasi menyusu dini telah disosialisasikan di Indonesia sejak Agustus 2007. World Health Organization (WHO) telah merekomendasikan kepada semua bayi untuk mendapatkan kolostrum yaitu ASI pada hari pertama dan kedua untuk melawan berbagai infeksi dan mendapatkan ASI sejak lahir selama 6 bulan. (Kemenkes, 2012).

Inisiasi menyusui dini (early initiation) atau permulaan menyusui dini adalah bayi mulai menyusu sendiri segera setelah lahir. Jadi,sebenarnya bayi manusia seperti juga bayi mamalia lain mempunyai kemampuan untuk menyusui sendiri. Asalkan dibiarkan kontak kulit bayi dengan kulit ibunya, setidaknya selama satu jam segera setelah lahir. Cara bayi melakukan insiasi menyusui dini disebut the breast crawl atau merangkak mencari payudara. (Haryono \& Setianingsih, 2014).
Menurut Roesli (2012) presentase

kematian balita dapat dicegah dengan beberapa intervensi yaitu IMD, menyusui eksklusif enam bulan dan diteruskan dengan memberikan makanan pendamping ASI (MP-ASI). IMD dapat mengurangi $22 \%$ kematian bayi 28 hari dari sekitar $40 \%$ kematian balita yang terjadi pada satu bulan pertama kehidupan bayi. Berarti IMD mengurangi angka kematian balita $88 \%$. (Roesli, 2012).

Inisiasi menyusu dini telah terbukti mampu menurunkan angka kematian neonatus. Penelitian yang dilakukan oleh Ghana terhadap 10.947 bayi lahir menunjukkan bahwa bayi yang diberi kesempatan menyusu dalam waktu satu jam pertama dan membiarkan kontak kulit ke kulit antara bayi dengan ibu, maka dapat mengurangi 22\% kematian bayi di 28 hari pertamanya. Penundaan dalam melakukan inisiasi menyusu dini akan meningkatkan risiko kematian pada masa neonatus yaitu bayi usia 0-18 hari. (Haryono \& Setianingsih, 2014).

Masalah kesehatan yang terjadi pada ibu dan anak masih menjadi pokok permasalahan utama di Indonesia, hal ini ditandai dengan masih tingginya Angka Kematian Ibu (AKI) dan Angka Kematian Bayi (AKB). Hal ini dilihat dari Hasil Survey Demografi dan Kesehatan Indonesia (SDKI) tahun 2012 diperoleh 
Ujung, Riance Mardiana, \& Nainggolan Dimpu Rismawaty. Pengaruh Penatalaksanaan IMD

Terhadap Keberhasilan Pemberian Asi Eksklusif Di Wilayah Kerja Puskesmas Onan

Hasang. Journal of Borneo Holistic Health, Vol.3, No. 1 Juni 2020 hal 26-33

AKI di Indonesia 359 per $100.000 \mathrm{KH}$

(Kelahiran Hidup) dan AKB 32 per 1000.

(Depkes, 2013).

Survei Demografi dan Kesehatan Indonesia (SDKI) pada tahun 2012 melaporkan bahwa $96 \%$ anak di bawah umur 2 tahun di Indonesia telah mendapat ASI. Namun, hanya $50 \%$ yang mendapat ASI dalam satu jam pertama setelah lahir dan hanya 66\% yang mendapat ASI dalam hari pertama setelah lahir. Prevalensi inisiasi menyusu dini di Indonesia sendiri masih lebih 4 rendah yaitu 39\%. Angka itu masih jauh tertinggal bila dibandingkan dengan negara-negara berkembang lain seperti Oman (85\%), Sri Lanka (75\%), dan Filipina (54\%) (Statistic Indonesia and Macro International, 2008). Hal ini menunjukkan program IMD di Indonesia belum terlaksana secara optimal. Peraturan Pemerintah Nomor 33 Tahun 2012 menginstruksikan kepada pemerintah daerah dan swasta untuk bekerjasama mendukung pemberian ASI Eksklusif dan Inisiasi Menyusu Dini (IMD). Melalui Peraturan Pemerintah, Pemerintah memformalkan hak perempuan untuk menyusui (termasuk di tempat kerja) dan melarang promosi pengganti ASI. Pemberian ASI Eksklusif dan IMD bertujuan untuk memenuhi kebutuhan nutrisi bayi dan mencegah kekurangan gizi pada balita. Pemerintah menyarankan daerah untuk menyediakan fasilitas khusus ibu menyusui di tempat kerja agar ibu tetap bisa menyusui bayinya. (Kemenkes, 2015).

Menurut WHO dan UNICEF (2012) laporan anak dunia 2011 yaitu dari 136,7 juta bayi lahir di seluruh dunia dan hanya $32,6 \%$ dari mereka yang disusui secara eksklusif dalam 6 bulan pertama. Sedangkan di negara industri, bayi yang tidak diberi ASI eksklusif lebih besar meninggal dari pada bayi yang diberi ASI eksklusif. Sementara di negara berkembang hanya 39\% ibu-ibu yang memberikan ASI eksklusif. (Siallagan, Mutiara, \& Yusad, 2013).

Hasil Riskesdas 2013 menyatakan bahwa persentase proses mulai mendapat ASI kurang dari satu jam (inisiasi menyusu dini) pada anak umur 0-23 bulan di Indonesia pada tahun 2013 sebesar 34,5\%. Persentase proses mulai mendapat ASI antara 1-6 jam sebesar 35,2\%, persentase proses mulai mendapat ASI antara 7-23 jam sebesar $3,7 \%$, sedangkan persentase proses mulai mendapat ASI antara 24-47 jam sebesar $13,0 \%$ dan persentase proses mulai mendapat ASI lebih dari 47 jam sebesar 13,7\%. (KementrianKesehatan, 2014)

Data menunjukkan bahwa rata-rata angka pemberian ASI Eksklusif di dunia baru berkisar 38\%. Di Indonesia meskipun sejumlah besar perempuan (96\%) menyusui anak mereka di kehidupan mereka, hanya 
Ujung, Riance Mardiana, \& Nainggolan Dimpu Rismawaty. Pengaruh Penatalaksanaan IMD

Terhadap Keberhasilan Pemberian Asi Eksklusif Di Wilayah Kerja Puskesmas Onan

Hasang. Journal of Borneo Holistic Health, Vol.3, No. 1 Juni 2020 hal 26-33

$42 \%$ dari bayi berusis 6 bulan yang mendapatkan ASI Eksklusif. (Pramita, 2017).

Berdasarkan hasil Suvey Demografi Kesehatan Indonesia (SDKI) yang dilakukan oleh BPS setiap 5 (lima) tahunan, diperoleh hasil bahwa AKB di Sumatera Utara mengalami penurunan dari tahun 1994 sebesar 61/1.000 KH, turun menjadi 42/1.000 KH pada SDKI tahun 2002. Namun pada tahun 2007 mengalami kenaikan menjadi 46/1.000 KH dan ada tahun 2012, menurun kembali menjadi sebesar 40/1.000 KH. (Sumut, 2012)

Di Kota Medan, berdasarkan profil Dinas Kesehatan Kota Medan pada bulan Agustus 2011 dari 39 Puskesmas yang ada di Medan terdapat 174 (4,08\%) bayi yang diberi ASI eksklusif dan terdapat 4089 (95,9\%) bayi yang tidak diberi ASI eksklusif. (Medan, 2011).

\section{Metode}

Penelitian ini merupakan penelitian kuantitatif dengan metode analitik dengan desain studi cross sectional (potong lintang), yaitu untuk melihat pengaruh inisisasi menyusu dini terhadap pemberian ASI Eksklusif dimana penelusuran dilakukan dengan melakukan wawancara dan menyebarkan kuesioner kepada responden.
Populasi dalam penelitian ini adalah seluruh ibu yang memiliki bayi usia 1 tahun sampai dengan 2 Tahun pada saat penelitian yang dilakukan di wilayah kerja puskesmas Onan Hasang, Kriteria inklusi dalam penelitian ini adalah ibu yang melahirkan secara normal. Teknik pengambilan sampel dengan menggunakan accidental sampling sebanyak 42 responden. (Notoatmodjo, 2010).

\section{Hasil}

Penelitian yang dilaksanakan di wilayah kerja puskesmas Onan Hasang.

Tabel.1 Karakteristik responden berdasarkan umur

\begin{tabular}{ccc}
\hline Kategori & Frekuensi & \% \\
\hline$<19$ & 5 & 11.9 \\
$20-35$ & 32 & 76.2 \\
$>35$ & 5 & 11.9 \\
\hline Total & 42 & 100 \\
\hline
\end{tabular}

Hasil penelitian berdasarkan karakteristik umur sebanyak 42 responden, dengan kategori umur <19 tahun sebanyak 5 responden (11.9\%), 20-35 tahun sebanyak 32 responden $(76.2 \%)$ dan $>35$ tahun sebanyak 5 responden (11.9\%).

Tabel. 2 Karakteristik responden berdasarkan Pendidikan

\begin{tabular}{ccc}
\hline Kategori & Frekuensi & \% \\
\hline Rendah & 29 & 69.0 \\
Tinggi & 13 & 31.0 \\
\hline Total & 42 & 100.0 \\
\hline
\end{tabular}

Hasil penelitian berdasarkan

karakteristik pendidikan sebanyak 42 
Ujung, Riance Mardiana, \& Nainggolan Dimpu Rismawaty. Pengaruh Penatalaksanaan IMD

Terhadap Keberhasilan Pemberian Asi Eksklusif Di Wilayah Kerja Puskesmas Onan

Hasang. Journal of Borneo Holistic Health, Vol.3, No. 1 Juni 2020 hal 26-33

responden, dengan kategori rendah

sebanyak 29 responden (69\%) dan kategori tinggi sebanyak 13 responden (31\%).

Tabel. 3 Karakteristik responden berdasarkan jumlah anak

\begin{tabular}{ccc}
\hline Kategori & Frekuensi & \% \\
\hline$>2$ & 21 & 50.0 \\
$<2$ & 21 & 50.0 \\
\hline \multirow{2}{*}{ Total } & 42 & 100.0 \\
\hline
\end{tabular}

Hasil penelitian berdasarkan karakteristik jumlah anak sebanyak 42 responden, dengan kategori kurang dari 2 sebanyak 21 responden dan lebih dari 2 sebanyak 21 responden.

Tabel. 4 Karakteristik responden berdasarkan Pendapatan

\begin{tabular}{ccc}
\hline Kategori & Frekuensi & \% \\
\hline$<2$ jt & 31 & 73.8 \\
$>2$ jt & 11 & 26.2 \\
\hline Total & 42 & 100 \\
\hline
\end{tabular}

Hasil penelitian berdasarkan karakteristik pendapatan sebanyak 42 responden, dengan kategori pendapatan $<2$ jt sebanyak 31 responden $(73.8 \%)$ dan $>2 \mathrm{jt}$ sebanyak 11 responden $(26.2 \%)$.

Tabel. 5 Karakteristik responden berdasarkan Pekerjaan

\begin{tabular}{ccc}
\hline Kategori & Frekuensi & \% \\
\hline Bekerja & 23 & 54.8 \\
Tidak Bekerja & 19 & 45.2 \\
\hline Total & 42 & 100.0 \\
\hline
\end{tabular}

Hasil penelitian berdasarkan karakteristik pekerjaan sebanyak 42 responden, dengan kategori bekerja sebanyak 23 responden $(54.8 \%)$ dan tidak bekerja sebanyak 19 responden $(45.2 \%)$

Tabel. 6 Karakteristik responden berdasarkan Pelaksanaan IMD

\begin{tabular}{ccc}
\hline Kategori & Frekuensi & \% \\
\hline Tidak dilakukan & 25 & 59.5 \\
Dilakukan & 17 & 40.5 \\
\hline Total & 42 & 100.0 \\
\hline
\end{tabular}

Hasil penelitian berdasarkan karakteristik berdasarkan pelaksanaan IMD sebanyak 42 responden, dengan kategori tidak dilaksanakan IMD sebanyak 25 responden $(59.5 \%)$ dan dilakukan IMD sebanyak 17 responden $(40.5 \%)$.

$\begin{array}{llll}\text { Tabel. } & 7 & \text { Karakteristik } & \text { responden }\end{array}$ berdasarkan ASI Eksklusif

\begin{tabular}{ccc}
\hline Kategori & Frekuensi & \% \\
\hline Tidak ASI & 23 & 54.8 \\
ASI Ekslusif & 19 & 45.2 \\
\hline Total & 42 & 100.0 \\
\hline
\end{tabular}

Hasil penelitian berdasarkan karakteristik ASI Eksklusif sebanyak 42 responden (100\%), dengan kategori tidak ASI sebanyak 23 responden $(54.8 \%)$ dan kategori ASI Eksklusif sebanyak 19 responden $(45.2 \%)$.

Tabel.8 Hubungan antara Umur dengan Pemberian ASI Eksklusif

\begin{tabular}{ccccc}
\hline UMUR & \multicolumn{2}{c}{ ASI EKSLUSIF } & $\%$ & $\begin{array}{c}\text { Sign } \\
(\boldsymbol{p})\end{array}$ \\
\cline { 2 - 3 } & Tdk ASI & ASI & & \\
\hline$<19$ & 5 & 5 & 23.8 & \\
$20-35$ & 13 & 9 & 52.4 & 1.000 \\
$>35$ & 5 & 5 & 23.8 & \\
\hline Total & 23 & 19 & 100 & \\
\hline
\end{tabular}

Dari hasil tabel diatas dengan hasil sign (p) 1.000 diperoleh hasil bahwa tidak 
Ujung, Riance Mardiana, \& Nainggolan Dimpu Rismawaty. Pengaruh Penatalaksanaan IMD

Terhadap Keberhasilan Pemberian Asi Eksklusif Di Wilayah Kerja Puskesmas Onan

Hasang. Journal of Borneo Holistic Health, Vol.3, No. 1 Juni 2020 hal 26-33

ada hubungan antara umur dengan

\begin{tabular}{|c|c|c|c|c|}
\hline Bekerja & 19 & 4 & 23 & \\
\hline $\begin{array}{c}\text { Tidak } \\
\text { bekerja }\end{array}$ & 4 & 15 & 19 & 0.000 \\
\hline Total & 23 & 19 & 100 & \\
\hline
\end{tabular}

Table.9 Hubungan antara Pendidikan dengan Pemberian ASI Eksklusif

\begin{tabular}{ccccc}
\hline \multirow{2}{*}{$\begin{array}{c}\text { Pendidik } \\
\text { an }\end{array}$} & \multicolumn{2}{c}{ ASI EKSLUSIF } & $\%$ & \multirow{2}{*}{$\begin{array}{c}\text { Sign } \\
(\boldsymbol{p})\end{array}$} \\
\cline { 2 - 3 } Tdk ASI & ASI & & \\
\hline Rendah & 17 & 12 & 69 & \\
Tinggi & 13 & 9 & 31 & 0.678 \\
\hline Total & 23 & 19 & 100 & \\
\hline
\end{tabular}

Dari hasil tabel diatas dengan hasil sign (p) 0.000 diperoleh hasil bahwa ada hubungan antara pekerjaan dengan pemberian ASI Eksklusif.

Dari hasil tabel diatas dengan hasil sign (p) 0.678 diperoleh hasil bahwa tidak ada hubungan antara pendidikan dengan pemberian ASI Eksklusif.

Tabel.10 Hubungan antara Jumlah Anak/ Paritas dengan Pemberian ASI Eksklusif

\begin{tabular}{|c|c|c|c|c|}
\hline \multirow[t]{2}{*}{ Paritas } & \multicolumn{2}{|c|}{ ASI EKSLUSIF } & \multirow[t]{2}{*}{$\%$} & \multirow{2}{*}{$\begin{array}{c}\text { Sign } \\
(p)\end{array}$} \\
\hline & Tdk ASI & ASI & & \\
\hline 2 Anak & 15 & 6 & 50 & \multirow{3}{*}{0.063} \\
\hline$\geq 2$ Anak & 8 & 13 & 50 & \\
\hline Total & 54 & 19 & 100 & \\
\hline
\end{tabular}

Dari hasil table diatas dengan hasil sign (p) 0.063 diperoleh hasil bahwa tidak ada hubungan antara jumlah anak/paritas dengan pemberian ASI Eksklusif.

Tabel 11 Hubungan antara Pendapatan dengan Pemberian ASI Eksklusif

\begin{tabular}{ccccc}
\hline $\begin{array}{c}\text { Pendap } \\
\text { atan }\end{array}$ & \multicolumn{2}{c}{ ASI EKSLUSIF } & $\%$ & \multirow{2}{*}{\begin{tabular}{c} 
Sign \\
\cline { 2 - 3 }$(\boldsymbol{p})$
\end{tabular}} \\
\hline$<2 \mathrm{jt}$ & 17 & 14 & 31 & \\
$>2 \mathrm{jt}$ & 6 & 5 & 11 & 1.000 \\
\hline Total & 23 & 19 & 100 & \\
\hline
\end{tabular}

Dari hasil tabel diatas dengan hasil sign (p) 1.000 diperoleh hasil bahwa tidak ada hubungan antara pendapatan dengan pemberian ASI Eksklusif.

Tabel 12 Hubungan antara Pekerjaan dengan Pemberian ASI Eksklusif

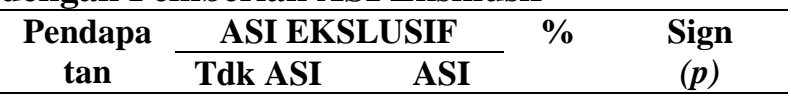

Tabel 13 Hubungan antara Pelaksanaan IMD dengan Pemberian ASI Eksklusif

\begin{tabular}{|c|c|c|c|c|}
\hline \multirow[t]{2}{*}{ IMD } & \multicolumn{2}{|c|}{ ASI EKSLUSIF } & \multirow[t]{2}{*}{$\%$} & \multirow{2}{*}{$\begin{array}{c}\text { Sign } \\
(p)\end{array}$} \\
\hline & Tdk ASI & ASI & & \\
\hline Dilakukan & 20 & 5 & 25 & \\
\hline $\begin{array}{c}\text { Tdk } \\
\text { dilakukan }\end{array}$ & 3 & 14 & 17 & 0.000 \\
\hline Total & 23 & 19 & 100 & \\
\hline
\end{tabular}

Dari hasil tabel diatas dengan hasil sign (p) 0.000 diperoleh hasil bahwa ada hubungan antara Pelaksanaan IMD dengan pemberian ASI Eksklusif.

Pengaruh Penatalaksanaan IMD terhadap Keberhasilan Pemberian ASI Eksklusif

Melakukan seleksi variable kandidat mutivariat. Bila hasil uji bivariatnya mempunyai nilai $p \leq 0.25$, maka variable tersebut dapat dimasukkan dalam model multivariate. Nilai $p$ setiap variable independent tersebut dapat dilihat pada tanel dibawah ini :

Tabel 14. Uji Bivariat

\begin{tabular}{lcc}
\hline \multicolumn{1}{c}{ Variable } & Sig. & $\operatorname{Exp}(\mathbf{B})$ \\
\hline JA & 0.112 & 4.808 \\
pekerjaan & 0.020 & 8.601 \\
IMD & 0.011 & 11.792 \\
Constant & 0.003 & 0.042 \\
\hline
\end{tabular}


Ujung, Riance Mardiana, \& Nainggolan Dimpu Rismawaty. Pengaruh Penatalaksanaan IMD

Terhadap Keberhasilan Pemberian Asi Eksklusif Di Wilayah Kerja Puskesmas Onan

Hasang. Journal of Borneo Holistic Health, Vol.3, No. 1 Juni 2020 hal 26-33

Ibu rumah tangga akan lebih besar 8 kali

memberikan ASI Eksklusif dibandingkan dengan ibu yang bekerja $(\operatorname{Exp}(\mathrm{B})=8.601$. ibu yang berhasil melaksanakan IMD akan lebih besar 11 kali memberikan ASI Eksklusif disbanding dengan ibu yang tidak melakukan IMD.

\section{Pembahasan}

Mayoritas responden berdasarkan Karakteristik umur 20 - 35 tahun sebanyak 32 responden $(76.2 \%)$ dengan hasil $p=$ 1.000 sehingga dapat disimpulkan bahwa antara umur dengan pemberian ASI Ekslusif tidak ada hubungan. Penelitian ini sejalan dengan penelitian yang dilakukan oleh Mayaningtyas Esya Utami dengan hasil uji statistik chi square, menunjukkan p value $=0,088(\mathrm{p}>0,05)$ artinya tidak ada hubungan antara umur ibu dengan keberhasilan pemberian ASI eksklusif (Utami \& Werdani, 2017)

Mayoritas responden berdasarkan karakteristik pendidikan adalah berpendidikan rendah 29 (69\%) dengan hasil $p=0.678$ sehingga dapat disimpulkan bahwa antara pendidikan dengan pemberian ASI Eksklusif tidak ada hubungan. Penelitian ini tidak sama dengan penelitian yang dilakukan oleh Deslina di Palembang yang mengatakan bahwa pendidikan berhubungan terhadap pemberian ASI Eksklusif hasil $\mathrm{p}=0.023$
(Deslima, Misnaniarti, \& Zulkarnain, 2019).

Karakteristik berdasarkan jumlah anak dengan hasil $p=0.063$ sehingga dapat disimpulkan bahwa antara jumlah anak dengan pemberian ASI Eksklusif tidak ada hubungan. Penelitian tersebut sejalan dengan penelitian yang dilakukan oleh Mayaningtyas Esya Utami Hasil uji statistik chi square menunjukkan bahwa $p$ value $=0,920(\mathrm{p}>0,05)$ artinya tidak ada hubungan antara paritas dengan keberhasilan pemberian ASI eksklusif (Utami \& Werdani, 2017).

Mayoritas responden berdasarkan karakteristik pendapatan adalah >2 jt sebanyak 31 responden (73.8\%) dengan hasil $p=1.000$ sehingga dapat disimpulkan bahwa antara pendapatan dengan pemberian ASI Eksklusif tidak ada berhubungan. Pendapatan dan pekerjaan peneltian ini sejalan dengan penelitian yang dilakukan oleh Deviana dengan Hasil penelitian $p=0.170$ menunjukkan bahwa tidak ada hubungan antara pendapatan keluarga dengan pemberian ASI Eksklusif (Ayutifanie, 2015).

Mayoritas responden berdasarkan karakteristik pekerjaan adalah bekerja sebanyak 23 responden (54.8\%) dengan hasil $p=0.000$ bahwa ada hubungan antara pekerjaan dengan pemberian ASI Eksklusif. Hasil penelelitian ini sejalan 
Ujung, Riance Mardiana, \& Nainggolan Dimpu Rismawaty. Pengaruh Penatalaksanaan IMD

Terhadap Keberhasilan Pemberian Asi Eksklusif Di Wilayah Kerja Puskesmas Onan

Hasang. Journal of Borneo Holistic Health, Vol.3, No. 1 Juni 2020 hal 26-33

dengan hasil penelitian Deslima didapatkan

nilai ( $\mathrm{p}$-value $>0,05=0,001$ ) yang berarti

bahwa terdapat hubungan yang bermakna antara IMD. (Deslima et al., 2019).

Mayoritas responden berdasarkan karakteristik pelaksanaan IMD adalah tidak dilakukan sebanyak 25 responden $(59.5 \%)$ dengan hasil $\mathrm{p}=0.000$ bahwa ada hubungan antara pelaksanaan IMD dengan pemberian ASI Eksklusif. Hasil tersebut sesuai dengan hasil penelitian yang dilakukan oleh Sandra Harianis dengan hasil $\mathrm{p}=0.007$ yang artinya ada hubungan antar IMD dengan pemberian ASI Eksklusif (Harianis, 2016).

Hasil uji multivariate menunjukkan bahwa jumlah anak (paritas) $p=0.112$ $\operatorname{Exp}(B) 4.808$ yang artinya tidak ada pengaruh antara jumlah anak dengan pemberian ASI Eksklusif, sedangkan hasil multivariate dari pekerjaan $\mathrm{p}=0.020 \operatorname{Exp}(\mathrm{B})$ 8.601 dan penatalaksaan IMD sebesar $p=0.011 \operatorname{Exp}(\mathrm{B}) 11.792$ yang artinya ada pengaruh antara pekerjaan dan penatalaksanaan IMD dengan Pemberian ASI Eksklusif.

\section{Kesimpulan}

Berdasarkan hasil dari penelitian diatas bahwa pekerja dan penatalaksanaan IMD berpengaruh terhadap keberhasilan pemberian ASI Eksklusif. Sehingga peneliti mengajak ibu yang akan mempunyai anak dan yang mempunyai anak untuk mau memperhatikan kebutuhan nutrisi bayinya. Ibu haruslah mau melakukan inisiasi menyusui secara dini sejak bayi tersebut lahir sehingga terpenuhi kebutuhan bayi dan ibu harus memperhatikan cara menyusui bayi dengan benar sehingga penatalaksanaan IMD dapat berjalan dengan baik.

\section{Referensi}

Ayutifanie, D. (2015). Hubungan antara Inisiasi Menyusu Dini (IMD) dengan Pemberian ASI Eksklusif pada Ibu Primipara dengan Bayi Usia> 6-12 Bulan (The Correlation between Early Initiation of Breast-feeding (IMD) with Exclusive Breastfeeding in the Primiparous Mother and the Baby in more than> 6 until 12 Months Old). JOUR.

Depkes, R. I. (2013). Riset kesehatan dasar 2013. Jakarta: Depkes RI. JOUR.

Deslima, N., Misnaniarti, M., \& Zulkarnain, H. M. (2019). ANALISIS HUBUNGAN INISISI MENYUSU DINI (IMD) TERHADAP PEMBERIAN ASI EKSKLUSIF DI WILAYAH KERJA PUSKESMAS MAKRAYU KOTA PALEMBANG. JUMANTIK (Jurnal Ilmiah Penelitian Kesehatan), 4(1), 1-14. JOUR.

Harianis, S. (2016). HUBUNGAN 
Ujung, Riance Mardiana, \& Nainggolan Dimpu Rismawaty. Pengaruh Penatalaksanaan IMD

Terhadap Keberhasilan Pemberian Asi Eksklusif Di Wilayah Kerja Puskesmas Onan Hasang. Journal of Borneo Holistic Health, Vol.3, No. 1 Juni 2020 hal 26-33

INISIASI MENYUSU DINI

TERHADAP PEMBERIAN ASI

EKSKLUSIF DI UPT PUSKESMAS

GAJAH MADAKABUPATEN

INDRAGIRI HILIR. SELODANG

$M A Y A N G$, 2(3). JOUR.

Haryono, R., \& Setianingsih, S. (2014).

Manfaat ASI eksklusif untuk buah hati anda. Yogyakarta: Gosyen

Publishing, 1-30. JOUR.

Kemenkes, R. I. (2012). Peraturan

Pemerintah (PP) Republik Indonesia

Nomor 33 tentang Pemberian ASI

Eksklusif. GEN, Jakarta: Kemenkes

RI.

Kemenkes, R. I. (2015). Profil Kesehatan

Indonesia $2015 . \quad$ Jakarta:

Kementerian Kesehatan Republik

Indonesia. JOUR.

KementrianKesehatan, R. I. (2014). Riset

kesehatan dasar 2013. Jakarta:

KementerianKesehatanRepublik

Indonesia. JOUR.

Medan, D. K. (2011). Profil Kesehatan Kota Medan Tahun 2010. GEN, Medan.

Notoatmodjo, S. (2010). Metododologi Penelitian Kesehatan. JOUR.

Pramita, E. (2017). Pekan ASI Sedunia 2017: Mari dukung Keberhasilan Ibu Menyusui. Diterbitkan tanggal 01/08/2017. GEN.

Roesli, U. (2012). Panduan: inisiasi menyusu dini: plus asi eksklusif. BOOK, Pustaka Bunda.

Siallagan, Y., Mutiara, E., \& Yusad, Y. (2013). Faktor Yang Berhubungan Dengan Pemberian Asi Eksklusif Pada Bayi (0-6 Bulan) Di Kelurahan Bantan Kecamatan Medan Tembung Tahun 2013. Gizi, Kesehatan Reproduksi Dan Epidemiologi, 2(3). JOUR.

Sumut, D. (2012). Profil Kesehatan Provinsi Sumatera Utara Tahun 2012. Sumatera Utara. Diakses Tanggal, 26. JOUR.

Utami, M. E., \& Werdani, K. E. (2017). Hubungan Pelaksanaan Inisiasi Menyusu Dini (IMD) Dan Faktor Sosiodemografi Ibu Dengan Keberhasilan Pemberian ASI Eksklusif Pada Bayi Usia 6-11 Bulan Di Wilayah Kerja Puskesmas Baki Sukoharjo. DISS, Universitas Muhammadiyah Surakarta.

Wiji, R. N. (2013). ASI dan panduan ibu menyusui. Yogyakarta: Nuha Medika, 75-76. JOUR. 